\title{
Assessment and Distribution of Macro and Micro Nutrients in Different Soil Series of District Swabi, Khyber Pakhtunkhwa, Pakistan
}

\author{
Aftab Jamal ${ }^{1, *}$, and Hifsa Jamal ${ }^{2}$ \\ ${ }^{1}$ Department of Soil and Environmental Sciences, Agricultural University, Peshawar, Pakistan \\ ${ }^{2}$ Department of Chemistry, Abdul Wali Khan University, Mardan, Pakistan \\ aftabses98@gmail.com
}

Keywords: Physiochemical properties, Swabi soil, Calcareous.

\begin{abstract}
In order to investigate the soil fertility status of Swabi district the present research was carried out. A total of 32 soil samples were collected from 16 different locations surrounding Swabi area at $0-20 \mathrm{~cm}$ and $20-40 \mathrm{~cm}$ depths and analysed for different chemical properties and fertility status in the laboratory of soil and environmental Sciences University of Agriculture Peshawar. Results revealed that soil of Swabi was moderately to strongly calcareous in nature and alkaline in reaction. The O.M content was found deficient to marginal, being deficient in $75 \%$ and marginal in $25 \%$ samples at both soil depths. AB-DTPA Extractable phosphorous was found sufficient (40\%) at surface soil while at sub surface it was found $15 \%$ deficient. No potassium deficiency was observed at surface as well as at sub surface soil, being sufficient in $37 \%$ samples at surface soil and $43 \%$ samples at sub surface soil. AB-DTPA extractable $\mathrm{Cu}$ was found adequate in almost all soil samples, Fe was found sufficient in $78 \%$ soil samples and medium in $9 \%$ samples and was found low in $12 \%$ soil samples at both soil depths. AB-DTPA Extractable $\mathrm{Zn}$ was found $12 \%$ deficient, $6 \%$ medium and 31\% adequate at all surface soil samples while at sub surface it was found $19 \%$ deficient, $22 \%$ medium and $12 \%$ adequate. Proper fertilization and application of FYM and green manure is highly recommended for the areas low in Organic matter and respective nutrients.
\end{abstract}

\section{Introduction}

The most precious and real wealth of a nation is its soil. Soil is one of the basic and integral components of our environment that serves as a medium for crop growth. Understanding and analysing the status of the soil is must and paramount for achieving profitable yield.

Soil fertility refers to the ability of soil to provide all essential elements without any toxic concentration required for plant growth. Fertility therefore, is a useful indicator used for achieving economical yield in agriculture production [1].

A number of factors are involved in decreasing agriculture crop production in Pakistan among which soil fertility finds its deserved place [2]. The yields as well as quality of almost all crops in Pakistan are well below than their potentials as compared to the other developed and developing countries of the world [3]. Due to poor status of available nutrients Pakistani soils are unable to support optimum levels of crop productivity [4]. The nutrients like $\mathrm{P}, \mathrm{N}$ and $\mathrm{K}$ are required in larger and on regular basis to the crops and are referred as macro nutrients, while micro nutrients like Fe, $\mathrm{Cu}$ and $\mathrm{Zn}$ are required in smaller amount as compared with macro nutrients and perform a vital role in various physiological functions of crops [5]. Nitrogen is must and paramount for development of tissue of plants and also increased growth, similarly $\mathrm{P}$ plays a vital role in many physiological functions of the crops like cell divisions, root development as well as fruit development [6]. $\mathrm{K}$ improves the size of grains and quality of fruits and it is also involve in activation of enzymes [7].

The rise in intensity of cultivation, adoption of high yielding varieties and the increased use of high analysis fertilizer materials as well as the nature of Pakistan soils have resulted in micronutrient deficiencies. Numerous researchers reported the deficiencies of macro and micro nutrients in KPK soils [8, 2]. Deficiencies of N, P, Zn, Cu, and B in Banu and Kohat districts of KP were also reported by [9]. 
Keeping in mind all these nutrients (macro and micro) importance for crop yield this study was organized with the main aim to evaluate the fertility status of Swabi soil by determining the chemical characteristics and to find the current status of macro and micro nutrients of the area for better nutrients management.

\section{Location and Description of study area}

Swabi is situated at $34^{\circ} 77^{\prime}, 48^{\prime \prime} \mathrm{N}$ and $72^{\circ} 28^{\prime}, 11^{\prime \prime} \mathrm{E}$ of Khyber Pakhtun Khwa, Pakistan, at elevation of 341 meter above the sea level and located at the bank of river Indus and Kabul. It is one the most crowded region of Khyber Pakhtunkhwa, Pakistan, having an area of $1543 \mathrm{Km}^{2}$ with a total population of 1.625 million. A six path motorway associating Islamabad (capital of Pakistan) with Peshawar (KPK) goes through District Swabi, Ambar Inter change.

Swabi has a harsh climate. The summer season is extremely hot and temperature gradually rises from May to September and reaches to its maximum in the month of June i.e., $41.50{ }^{\circ} \mathrm{C}$. Intensive cultivation and artificial irrigation, makes the area humid and hot.

For agriculture point of view Swabi belongs to the most important belt of the country because it is the place of tobacco and sugar cane both of which are the most important cash crops of the country. Irrigation is mainly done through river water which carries many dissolved salts which will ultimately effects Swabi soils with passage of time. In the past no research work was done on these soils, basic information regarding with recommended fertilizer doses and nutrient status of these soils will become available from the present research.

\section{Material and Methods}

A total of 32 different soil samples were collected from 16 different locations of Swabi, at 0-20 cm and 20-40 cm depth (Table 1). The collected soils samples were brought to the Laboratory of soil and environmental sciences were air dried in shade followed by sieving through $2 \mathrm{~mm}$ sieve, stored in plastic bags and then analysed for various soil chemical characteristics like EC, $\mathrm{pH}$ [10]., lime content [11], and OM [12]. Soil fertility status was determined by analysing AB-DTPA Extractable $\mathrm{P}, \mathrm{K} \mathrm{Zn}, \mathrm{Fe}$, and $\mathrm{Cu}$ [13]. The recorded data were subjected to simple arithmetic means and standard deviation.

\section{Results and Discussion}

The results with relevant discussion on chemical properties and fertility status of Swabi soil are as under.

\section{Soil Chemical Properties}

\section{Soil Organic matter, Lime content, $\mathrm{pH}$ and EC:}

At surface soil the organic matter content ranged from $0.33 \%$ at Mughal Kot to $1.56 \%$ at Sodher soil; while at sub surface soil it ranged from a minimum of $0.21 \%$ at Gohati to $1.11 \%$ at Sodher soil (Table 1). O.M content of all soil samples were ranged from low to medium, being medium in $25 \%$ samples while the rest of $75 \%$ were found low in O.M at both soil depths (Table 1). Pakistani soils are deficient in organic matter content so as Swabi soil too. Data revealed that O.M at soil surface was more as compared to sub surface (Table 1) and it might be due to greater amount of residue on surface as compared with sub surface. Our results was in lined with the published values,[14] also reported less amount of O.M $(0.26 \%)$ for the same soil series. Poor fertility status of the soil having low O.M was also reported by [15-17]. Soils of Pakistan are deficient (less than $1 \%$ ) in O.M and with addition of compost and organic matter it can be replenished [18]. Low O.M content of the soil may be associated with warmer climate of the area as well as restricted use of FYM [3]. 
Lime content of the surface soil ranged from a minimum of $5.76 \%$ at Turlandi to a maximum of $8.75 \%$ at Yar hussain region with a mean value of $7.30 \%$ (Table 1), and at sub surface soil lime content ranged from $6.56 \%$ at Adina soil to a maximum of $9.0 \%$ at Chota Lahore soil with a mean of 7.97\% (Table 1). Results revealed that lime content gradually increased with soil depth (Table 1). Swabi soil was found highly calcareous in nature. Calcareous nature of Pakistani soil was also reported by [19]. This $\mathrm{CaCO}_{3}$ not only increase the soil $\mathrm{pH}$, but also interfere with the soil property by the chemo-sorption of anions and cations [20]. Deficiencies of P, Zn, and Fe are well known phenomenon in calcareous soil [21].

Calcite $\left(\mathrm{CacO}_{3}\right)$ is the most dominant soil mineral in Pakistani soil, comes from parent materials, wind deposition and ground water [22]. According to [23] Pakistani soils are derived from alluvium loess material, having alkaline reaction, calcareous in nature and low in available O.M content and ultimately deficient in many essential plant nutrients.

Soil reaction or soil $\mathrm{pH}$ is an important indicator of soil acidity or alkalinity and helps in identification of chemical nature of the soil [24]. At surface soil $(0-20 \mathrm{~cm}) \mathrm{pH}$ of the soil ranged from a minimum of 7.5 at Malik Abad soil series to a maximum of 8.6 at Char Bagh soil with a mean value of 8.29 , while at sub surface $(20-40 \mathrm{~cm}) \mathrm{pH}$ of the soil ranged from a minimum of 7.2 at Malik Abad to a maximum of 8.46 at Chota Lahore soil with a mean value of 8.0 (Table 1). Results further revealed that soil of Swabi district was alkaline in reaction. The high $\mathrm{pH}$ values might be associated with the presence of soluble exchangeable sodium along with $\mathrm{HCO}_{3}{ }^{-}$ion and during evaporation precipitates calcium and magnesium carbonates [25]. While the alkalinity problem in soil was associated with calcareous parent materials coupled with low O.M content of soil [26]. Our results were similar to that of $[17,3]$. However, $\mathrm{pH}$ is not an accepted criterion because it tends to be buffered by soil and most crops can tolerate a wide range of $\mathrm{pH}$ [27].

Electrical Conductivity is the measurement of soluble salts present in the soil and greatly affected by application of organic and in organic fertilizers, cropping pattern as well as the water used for irrigation purpose [25]. Electrical conductivity of soil samples ranged from a minimum of $0.13 \mathrm{dSm}^{-1}$ at Maneri to a maximum of $0.56 \mathrm{dSm}^{-1}$ at Dagi at surface soil while at sub surface it ranged from minimum of $0.18 \mathrm{dSm}^{-1}$ at Char Bagh soil to a maximum of $0.46 \mathrm{dSm}^{-1}$ at Shewa soil series (Table 1). The mean value was $0.29 \mathrm{dSm}^{-1}$ at surface soil and $0.30 \mathrm{dSm}^{-1}$ at sub surface soil. Standard deviation was found greater at surface soil as compared with sub surface soil (Table 1), which was similar to the findings of [3]. Ec of the soil depends on amount of moisture hold by soil particles [14]. Our results were also in lined with the work of [28] concluded that these soils were normal with respect to salinity (Table 1). 
Table 1. Chemical properties (pH, E.C, $\mathrm{CaCO}_{3}$ and O.M) of surface $(0-20 \mathrm{~cm})$ and sub surface $(20-40 \mathrm{~cm})$ soil.

\begin{tabular}{|c|c|c|c|c|c|}
\hline Area Name & Depth(Cm) & pH & $\mathrm{EC}\left(\mathrm{dSm}^{-1}\right)$ & $\begin{array}{c}\mathrm{CaCO}_{3} \\
(\%)\end{array}$ & $\begin{array}{l}\text { OM } \\
(\%)\end{array}$ \\
\hline \multirow{2}{*}{ Dagai } & $0-20$ & 8.4 & 0.56 & 6.25 & $0.51 \mathrm{~L}$ \\
\hline & $20-40$ & 7.8 & 0.24 & 8.75 & $0.21 \mathrm{~L}$ \\
\hline \multirow{2}{*}{ Dandoqa } & $0-20$ & 8.4 & 0.28 & 6.75 & $0.62 \mathrm{~L}$ \\
\hline & $20-40$ & 7.8 & 0.36 & 8.51 & $0.31 \mathrm{~L}$ \\
\hline \multirow[t]{2}{*}{ Turlandi } & $0-20$ & 8.5 & 0.23 & 5.76 & $0.71 \mathrm{~L}$ \\
\hline & $20-40$ & 8.4 & 0.25 & 8.75 & $0.33 \mathrm{~L}$ \\
\hline \multirow[t]{2}{*}{ Shewa } & $0-20$ & 7.7 & 0.36 & 8.25 & $1.43 \mathrm{M}$ \\
\hline & $20-40$ & 8.2 & 0.46 & 7.7 & $0.96 \mathrm{~L}$ \\
\hline \multirow[t]{2}{*}{ Kalu Khan } & $0-20$ & 8.6 & 0.27 & 7.51 & $0.81 \mathrm{~L}$ \\
\hline & $20-40$ & 7.5 & 0.35 & 7.98 & $0.45 \mathrm{~L}$ \\
\hline \multirow[t]{2}{*}{ Adina } & $0-20$ & 8.3 & 0.22 & 7.75 & $0.35 \mathrm{~L}$ \\
\hline & $20-40$ & 7.7 & 0.32 & 6.56 & $0.22 \mathrm{~L}$ \\
\hline \multirow[t]{2}{*}{ Ismaila } & $0-20$ & 8.5 & 0.25 & 7.01 & $1.35 \mathrm{M}$ \\
\hline & $20-40$ & 8.4 & 0.28 & 8.51 & $0.98 \mathrm{~L}$ \\
\hline \multirow[t]{2}{*}{ Yar hussain } & $0-20$ & 8.3 & 0.27 & 8.75 & $0.97 \mathrm{~L}$ \\
\hline & $20-40$ & 7.7 & 0.32 & 6.92 & $0.45 \mathrm{~L}$ \\
\hline \multirow[t]{2}{*}{ Chota Lahore } & $0-20$ & 8.5 & 0.31 & 8.50 & $1.11 \mathrm{M}$ \\
\hline & $20-40$ & 8.46 & 0.35 & 9.02 & $0.62 \mathrm{~L}$ \\
\hline \multirow[t]{2}{*}{ Maneri } & $0-20$ & 8.4 & 0.13 & 6.50 & $1.55 \mathrm{M}$ \\
\hline & $20-40$ & 7.7 & 0.36 & 8.21 & $0.75 \mathrm{~L}$ \\
\hline \multirow[t]{2}{*}{ Gohati } & $0-20$ & 7.8 & 0.32 & 6.81 & $0.73 \mathrm{~L}$ \\
\hline & $20-40$ & 8.2 & 0.26 & 7.52 & $0.21 \mathrm{~L}$ \\
\hline \multirow[t]{2}{*}{ Char bagh } & $0-20$ & 8.6 & 0.17 & 7.22 & $1.11 \mathrm{M}$ \\
\hline & $20-40$ & 8.3 & 0.18 & 8.21 & $0.82 \mathrm{~L}$ \\
\hline \multirow[t]{2}{*}{ Malik abad } & $0-20$ & 7.5 & 0.35 & 5.97 & $0.64 \mathrm{~L}$ \\
\hline & $20-40$ & 7.2 & 0.36 & 7.27 & $0.38 \mathrm{~L}$ \\
\hline \multirow[t]{2}{*}{ Nawe Kali } & $0-20$ & 8.3 & 0.38 & 8.45 & $1.21 \mathrm{M}$ \\
\hline & $20-40$ & 8.4 & 0.25 & 8.81 & $0.92 \mathrm{~L}$ \\
\hline \multirow[t]{2}{*}{ Mughal Kot } & $0-20$ & 8.5 & 0.24 & 6.98 & $0.33 \mathrm{~L}$ \\
\hline & $20-40$ & 8.1 & 0.35 & 7.77 & $0.95 \mathrm{~L}$ \\
\hline \multirow[t]{2}{*}{ Sodher } & $0-20$ & 8.4 & 0.36 & 8.51 & $1.56 \mathrm{M}$ \\
\hline & $20-40$ & 7.8 & 0.22 & 7.21 & $1.11 \mathrm{M}$ \\
\hline \multirow{2}{*}{$\begin{array}{l}\text { Minimum } \\
\text { values }\end{array}$} & $0-20$ & 7.5 & 0.13 & 5.76 & 0.33 \\
\hline & $20-40$ & 7.2 & 0.18 & 6.56 & 0.21 \\
\hline \multirow{2}{*}{$\begin{array}{l}\text { Maximum } \\
\text { values }\end{array}$} & $0-20$ & 8.6 & 0.56 & 8.75 & 1.56 \\
\hline & $20-40$ & 8.46 & 0.46 & 9.0 & 1.11 \\
\hline \multirow[t]{2}{*}{ Mean values } & $0-20$ & 8.29 & 0.29 & 7.30 & 0.93 \\
\hline & $20-40$ & 8.00 & 0.30 & 7.97 & 0.60 \\
\hline \multirow[t]{2}{*}{ S.D } & $0-20$ & 0.32 & 0.099 & 0.96 & 0.409 \\
\hline & $20-40$ & 0.37 & 0.077 & 0.74 & 0.32 \\
\hline
\end{tabular}

$L$, and $M$, stands for low and medium respectively.

The soil pH and EC were determined in 1:5 soil water suspensions. 


\section{Soil Fertility Status}

\section{AB-DTPA Extractable Potassium and Phosphorous (mg/kg)}

At surface soil AB-DTPA Extractable Potassium ranged from a minimum of 87.8 to a maximum of $200 \mathrm{mg} \mathrm{kg}^{-1}$ at Dagi region with a mean value of $136 \mathrm{mg} \mathrm{kg}^{-1}$, while at sub surface it ranged from 89.5 at Kalu Khan to a maximum of $150 \mathrm{mg} \mathrm{kg}^{-1}$ at Ismaila with mean value of $110 \mathrm{mg}$ $\mathrm{kg}^{-1}$ (Table 2). The standard deviation value at surface soil (33.4) was greater than sub surface soil (14.9) showed a great variations among all sample values (Table 2). No potassium deficiency was observed in surface as well as in sub surface soil, being sufficient in $37 \%$ samples in surface soil and $43 \%$ samples in sub surface soil (Table 2). Potassium catalytic in nature exists in $\mathrm{K}^{+}$form involved in the activation of large number of enzymes which performs a key role in various plant physiological processes [25]. It has also been reported by many investigators that Pakistani soils are rich in available $\mathrm{K}[3,29]$. However, response to potassium has also been observed in sugarcane [30], rice, vegetables and crops sown on sandy soil [31]. Similarly the application of potash fertilizer to tobacco and cotton is an acceptable practice in all areas of Pakistan [32].

AB-DTPA Extractable phosphorous content of soil surface ranged from a minimum of $1.58 \mathrm{mg} \mathrm{kg}^{-1}$ at Sodher to a maximum of $15.4 \mathrm{mg} \mathrm{kg}^{-1}$ at Mughal Kot with a mean value of $8.87 \mathrm{mg} \mathrm{kg}^{-1}$ while soil of Gohati showed a minimum value of $2.11 \mathrm{mg} \mathrm{kg}^{-1}$ and soil of Yar Hussain exhibited a maximum value of $9.2 \mathrm{mg} \mathrm{kg}^{-1}$ with a mean of $5.48 \mathrm{mg} \mathrm{kg}^{-1}$ at sub surface soil (Table 2). $40 \%$ of all soil samples of surface soil were found sufficient in $\mathrm{P}$ and it might be due to the present materials, while at sub surface it was found $15 \%$ deficient (Table 2), and it might be due to the immobile nature of $\mathrm{P}$ in soil. Surface soil posses more $\mathrm{P}$ as compared with the sub surface soil. [3, 2] also reported $\left(<10 \mathrm{mg} \mathrm{kg-}^{1}\right) \mathrm{P}$ content in KP soil. Most of Pakistan soils are calcareous in nature, which are not only low in the parent material containing the phosphorus mineral but its alkaline nature further reduces its availability in soil [33, 34, 19, 35].

AB-DTPA Extractable Fe ranged from a minimum of $2.43 \mathrm{mg} \mathrm{kg}^{-1}$ at Dagi soil to a maximum of $11.52 \mathrm{mg} \mathrm{kg}^{-1}$ at Malik Abad with a mean of $7.66 \mathrm{mg} \mathrm{kg}^{-1}$ at soil surface, while at sub surface soil Fe ranged from minimum value of $1.55 \mathrm{mg} \mathrm{kg}^{-1}$ at Sodher region to a maximum value of $10.8 \mathrm{mg} \mathrm{kg}^{-1}$ at Gohati with a mean value of $6.33 \mathrm{mg} \mathrm{kg}^{-1}$ (Table 3). Fe was found sufficient in $78 \%$ soil samples and medium in $9 \%$ samples and was found low in $12 \%$ soil samples at both soil depths (Table 3). Our results were in lined with [36], reported sufficient iron in Pakistan soil. KP soils are sufficient in $\mathrm{Fe}$ [2]. However, [37] reported that in alkaline calcareous soil the availability of iron is limited because of high $\mathrm{pH}$ and calcium content. Fe availability was also found low in Indus plain of Pakistan [38].

AB-DTPA Extractable $\mathrm{Zn}$ ranged from a minimum of $0.35 \mathrm{mg} \mathrm{kg}^{-1}$ at Gohati to maximum of $4.05 \mathrm{mg} \mathrm{kg}^{-1}$ at Malik Abad at surface soil with a mean of $1.97 \mathrm{mg} \mathrm{kg}^{-1}$, while the sub surface of Dandoqa soil showed a minimum value of $0.1 \mathrm{mg} \mathrm{kg}^{-1}$ and Ismaila soil exhibited a maximum $\mathrm{Fe}$ concentration of $4.11 \mathrm{mg} \mathrm{kg}^{-1}$, with mean value of $1.22 \mathrm{mg} \mathrm{kg}^{-1}$ (Table 3). AB-DTPA Extractable $\mathrm{Zn}$ was found $12 \%$ deficient, $6 \%$ medium and $31 \%$ adequate in all surface soil samples while in sub surface it was found $19 \%$ deficient, $22 \%$ medium and $12 \%$ adequate (Table 3 ). Standard deviation was found similar at both soil depths. Our results were in lined with [3]. However, in Pakistan $\mathrm{Zn}$ deficiency is considered the third most serious crop nutrition problem [39], further more alkaline $\mathrm{pH}$ and low organic matter of Pakistani soils also contributes towards $\mathrm{Zn}$ deficiency [40]. High rate of adsorption in alkaline calcareous soil also favors $\mathrm{Zn}$ deficiency [41]. Moreover in alkaline calcareous soil chemisorptions of $\mathrm{Zn}$ with calcium carbonate further depletes $\mathrm{Zn}$ availability to plants [42]. 
Table 2. AB-DTPA extractable $P$ and $K$ in surface $(0-20 \mathrm{~cm})$ and subsurface $(20-40 \mathrm{~cm})$ soil.

\begin{tabular}{|c|c|c|c|}
\hline Area Name & $\operatorname{Depth}(\mathrm{Cm})$ & $\begin{array}{c}\text { Phosphorous } \\
\left(\mathrm{mg} \mathrm{kg}^{-1}\right)\end{array}$ & $\begin{array}{r}\text { Potassium } \\
\left(\mathrm{mg} \mathrm{kg}^{-1}\right)\end{array}$ \\
\hline \multirow[t]{2}{*}{ Dagai } & $0-20$ & $8 \mathrm{H}$ & $87.8 \mathrm{M}$ \\
\hline & $20-40$ & $5.4 \mathrm{M}$ & $100 \mathrm{M}$ \\
\hline \multirow{2}{*}{ Dandoqa } & $0-20$ & $8.8 \mathrm{H}$ & $100 \mathrm{M}$ \\
\hline & $20-40$ & $4.2 \mathrm{M}$ & $94 \mathrm{M}$ \\
\hline \multirow[t]{2}{*}{ Turlandi } & $0-20$ & $7.1 \mathrm{H}$ & $160 \mathrm{H}$ \\
\hline & $20-40$ & $6.6 \mathrm{M}$ & $110 \mathrm{M}$ \\
\hline \multirow[t]{2}{*}{ Shewa } & $0-20$ & $7.4 \mathrm{H}$ & $130 \mathrm{M}$ \\
\hline & $20-40$ & $6.8 \mathrm{M}$ & $105 \mathrm{M}$ \\
\hline \multirow[t]{2}{*}{ Kalu Khan } & $0-20$ & $9.8 \mathrm{H}$ & $100 \mathrm{M}$ \\
\hline & $20-40$ & $4.98 \mathrm{M}$ & $89.5 \mathrm{M}$ \\
\hline \multirow{2}{*}{ Adina } & $0-20$ & $10.5 \mathrm{H}$ & $90 \mathrm{M}$ \\
\hline & $20-40$ & $5.2 \mathrm{M}$ & $120 \mathrm{M}$ \\
\hline \multirow[t]{2}{*}{ Ismaila } & $0-20$ & $12.2 \mathrm{H}$ & $200 \mathrm{H}$ \\
\hline & $20-40$ & $4.9 \mathrm{M}$ & $150 \mathrm{H}$ \\
\hline \multirow[t]{2}{*}{ Yar hussain } & $0-20$ & $5.4 \mathrm{M}$ & $160 \mathrm{H}$ \\
\hline & $20-40$ & $9.2 \mathrm{H}$ & $110 \mathrm{M}$ \\
\hline \multirow[t]{2}{*}{ Chota Lahore } & $0-20$ & $9.4 \mathrm{H}$ & $110 \mathrm{M}$ \\
\hline & $20-40$ & $3.9 \mathrm{~L}$ & $120 \mathrm{M}$ \\
\hline \multirow[t]{2}{*}{ Maneri } & $0-20$ & $7.5 \mathrm{H}$ & $140 \mathrm{H}$ \\
\hline & $20-40$ & $3.62 \mathrm{~L}$ & $100 \mathrm{M}$ \\
\hline \multirow{2}{*}{ Gohati } & $0-20$ & $5.37 \mathrm{M}$ & $170 \mathrm{H}$ \\
\hline & $20-40$ & $2.11 \mathrm{~L}$ & $125 \mathrm{H}$ \\
\hline \multirow[t]{2}{*}{ Char bagh } & $0-20$ & $9.5 \mathrm{H}$ & $150 \mathrm{H}$ \\
\hline & $20-40$ & $4.46 \mathrm{M}$ & $105 \mathrm{M}$ \\
\hline \multirow[t]{2}{*}{ Malik abad } & $0-20$ & $12.5 \mathrm{H}$ & $130 \mathrm{H}$ \\
\hline & $20-40$ & $5.85 \mathrm{M}$ & $115 \mathrm{M}$ \\
\hline \multirow[t]{2}{*}{ Nawe Kali } & $0-20$ & $11.5 \mathrm{H}$ & $150 \mathrm{H}$ \\
\hline & $20-40$ & $5.7 \mathrm{M}$ & $100 \mathrm{M}$ \\
\hline \multirow[t]{2}{*}{ Mughal Kot } & $0-20$ & $15.4 \mathrm{H}$ & $180 \mathrm{H}$ \\
\hline & $20-40$ & $9.0 \mathrm{H}$ & $120 \mathrm{M}$ \\
\hline \multirow[t]{2}{*}{ Sodher } & $0-20$ & $1.58 \mathrm{~L}$ & $120 \mathrm{M}$ \\
\hline & $20-40$ & $5.82 \mathrm{M}$ & $97.7 \mathrm{M}$ \\
\hline \multirow[t]{2}{*}{ Minimum values } & $0-20$ & 1.58 & 87.8 \\
\hline & $20-40$ & 2.11 & 89.5 \\
\hline \multirow[t]{2}{*}{ Maximum values } & $0-20$ & 15.4 & 200 \\
\hline & $20-40$ & 9.2 & 150 \\
\hline \multirow[t]{2}{*}{ Mean values } & $0-20$ & 8.87 & 136.1 \\
\hline & $20-40$ & 5.48 & 110.0 \\
\hline \multirow[t]{2}{*}{ S.D } & $0-20$ & 3.3 & 33.4 \\
\hline & $20-40$ & 1.82 & 14.9 \\
\hline
\end{tabular}

$\mathrm{L}, \mathrm{M}$, and $\mathrm{H}$ stand for low, medium and high respectively.

AB-DTPA Extractable $\mathrm{Cu}, \mathrm{Fe}$, and $\mathrm{Zn}\left(\mathrm{mg} \mathrm{kg}^{-1}\right)$

AB-DTPA Extractable $\mathrm{Cu}$ ranged from a minimum of $2.33 \mathrm{mg} \mathrm{kg}^{-1}$ to a maximum of $19.15 \mathrm{mg} \mathrm{kg}^{-1}$ at Chota Lahore with mean of $6.46 \mathrm{mg} \mathrm{kg}^{-1}$ at soil surface, while at sub surface it ranged from $1.32 \mathrm{mg} \mathrm{kg}^{-1}$ at Gohati to maximum value of $14.11 \mathrm{mg} \mathrm{kg}^{-1}$ with mean value of 
$5.87 \mathrm{mg} \mathrm{kg}^{-1}$ (Table3). Sufficient $\mathrm{Cu}$ was found in almost all soil samples. Similar results were also reported by $[3,2,36]$. Decreased in soil $\mathrm{Cu}$ concentration with soil depth was also reported by [43, 44]. $\mathrm{Cu}$ deficiency is much less a problem in the alkaline soils of Pakistan and it is reported that its deficiency is less common than that of $\mathrm{Zn}, \mathrm{Fe}$, and B in Pakistan soils [45].

Table 3. AB-DTPA extractable $\mathrm{Cu}, \mathrm{Fe}$, and $\mathrm{Zn}$ in surface $(0-20 \mathrm{~cm})$ and Sub surface soils $(20-40 \mathrm{~cm})$.

\begin{tabular}{|c|c|c|c|c|}
\hline Area Name & $\operatorname{Depth}(\mathrm{Cm})$ & $\begin{array}{c}\mathrm{Fe} \\
\left(\mathrm{mg} \mathrm{kg}^{-1}\right)\end{array}$ & $\begin{array}{c}\mathrm{Zn} \\
\left(\mathrm{mg} \mathrm{kg}^{-1}\right)\end{array}$ & $\begin{array}{l}\mathrm{Cu} \\
\left.(\mathrm{mg} \mathrm{kg})^{-1}\right)\end{array}$ \\
\hline \multirow[t]{2}{*}{ Dagai } & $0-20$ & $2.43 \mathrm{~L}$ & $0.37 \mathrm{~L}$ & $4.4 \mathrm{H}$ \\
\hline & $20-40$ & $2.95 \mathrm{~L}$ & $0.21 \mathrm{~L}$ & $2.1 \mathrm{H}$ \\
\hline \multirow{2}{*}{ Dandoqa } & $0-20$ & $5.84 \mathrm{H}$ & $0.72 \mathrm{~L}$ & $3.54 \mathrm{H}$ \\
\hline & $20-40$ & $5.46 \mathrm{H}$ & $0.1 \mathrm{M}$ & $1.42 \mathrm{H}$ \\
\hline \multirow[t]{2}{*}{ Turlandi } & $0-20$ & $10.5 \mathrm{H}$ & $1.43 \mathrm{M}$ & $9.9 \mathrm{H}$ \\
\hline & $20-40$ & $10.8 \mathrm{H}$ & $0.91 \mathrm{M}$ & $6.1 \mathrm{H}$ \\
\hline \multirow[t]{2}{*}{ Shewa } & $0-20$ & $7.75 \mathrm{H}$ & $2.33 \mathrm{H}$ & $10.5 \mathrm{H}$ \\
\hline & $20-40$ & $6.77 \mathrm{H}$ & $1.11 \mathrm{M}$ & $14.11 \mathrm{H}$ \\
\hline \multirow[t]{2}{*}{ Kalu Khan } & $0-20$ & $9.32 \mathrm{H}$ & $1.78 \mathrm{H}$ & $5.7 \mathrm{H}$ \\
\hline & $20-40$ & $7.65 \mathrm{H}$ & $0.45 \mathrm{~L}$ & $6.54 \mathrm{H}$ \\
\hline \multirow[t]{2}{*}{ Adina } & $0-20$ & $8.11 \mathrm{H}$ & $1.99 \mathrm{H}$ & $4.56 \mathrm{H}$ \\
\hline & $20-40$ & $5.22 \mathrm{H}$ & $0.11 \mathrm{~L}$ & $5.64 \mathrm{H}$ \\
\hline \multirow[t]{2}{*}{ Ismaila } & $0-20$ & $4.32 \mathrm{M}$ & $3.92 \mathrm{H}$ & $6.56 \mathrm{H}$ \\
\hline & $20-40$ & $5.44 \mathrm{H}$ & $4.11 \mathrm{H}$ & $4.89 \mathrm{H}$ \\
\hline \multirow[t]{2}{*}{ Yar hussain } & $0-20$ & $10.91 \mathrm{H}$ & $1.04 \mathrm{M}$ & $8.77 \mathrm{H}$ \\
\hline & $20-40$ & $7.99 \mathrm{H}$ & $0.52 \mathrm{~L}$ & $9.99 \mathrm{H}$ \\
\hline \multirow{2}{*}{ Chota Lahore } & $0-20$ & $8.88 \mathrm{H}$ & $3.6 \mathrm{H}$ & $19.15 \mathrm{H}$ \\
\hline & $20-40$ & $9.11 \mathrm{H}$ & $3.22 \mathrm{H}$ & $11.32 \mathrm{H}$ \\
\hline \multirow{2}{*}{ Maneri } & $0-20$ & $9.25 \mathrm{H}$ & $2.76 \mathrm{H}$ & $2.59 \mathrm{H}$ \\
\hline & $20-40$ & $6.23 \mathrm{H}$ & $3.01 \mathrm{H}$ & $3.02 \mathrm{H}$ \\
\hline \multirow[t]{2}{*}{ Gohati } & $0-20$ & $10.5 \mathrm{H}$ & $0.35 \mathrm{~L}$ & $2.64 \mathrm{H}$ \\
\hline & $20-40$ & $10.8 \mathrm{H}$ & $1.11 \mathrm{M}$ & $1.32 \mathrm{H}$ \\
\hline \multirow[t]{2}{*}{ Char bagh } & $0-20$ & $7.9 \mathrm{H}$ & $2.85 \mathrm{H}$ & $5.63 \mathrm{H}$ \\
\hline & $20-40$ & $8.21 \mathrm{H}$ & $1.14 \mathrm{M}$ & $5.01 \mathrm{H}$ \\
\hline \multirow[t]{2}{*}{ Malik abad } & $0-20$ & $11.52 \mathrm{H}$ & $4.05 \mathrm{H}$ & $2.33 \mathrm{H}$ \\
\hline & $20-40$ & $6.84 \mathrm{H}$ & $1.54 \mathrm{M}$ & $4.46 \mathrm{H}$ \\
\hline \multirow[t]{2}{*}{ Nawe Kali } & $0-20$ & $6.23 \mathrm{H}$ & $1.77 \mathrm{H}$ & $4.11 \mathrm{H}$ \\
\hline & $20-40$ & $2.52 \mathrm{~L}$ & $0.86 \mathrm{~L}$ & $3.02 \mathrm{H}$ \\
\hline \multirow[t]{2}{*}{ Mughal Kot } & $0-20$ & $5.55 \mathrm{H}$ & $2.21 \mathrm{H}$ & $7.99 \mathrm{H}$ \\
\hline & $20-40$ & $3.86 \mathrm{M}$ & $1.09 \mathrm{M}$ & $10.89 \mathrm{H}$ \\
\hline \multirow[t]{2}{*}{ Sodher } & $0-20$ & $3.66 \mathrm{M}$ & $0.45 \mathrm{~L}$ & $5.02 \mathrm{H}$ \\
\hline & $20-40$ & $1.55 \mathrm{~L}$ & $0.11 \mathrm{~L}$ & $4.16 \mathrm{H}$ \\
\hline \multirow[t]{2}{*}{ Minimum values } & $0-20$ & 2.43 & 0.35 & 2.33 \\
\hline & $20-40$ & 1.55 & 0.11 & 1.32 \\
\hline \multirow[t]{2}{*}{ Maximum values } & $0-20$ & 11.52 & 4.05 & 19.15 \\
\hline & $20-40$ & 10.8 & 4.11 & 13.22 \\
\hline \multirow[t]{2}{*}{ Mean values } & $0-20$ & 7.66 & 1.97 & 6.46 \\
\hline & $20-40$ & 6.33 & 1.22 & 5.87 \\
\hline \multirow[t]{2}{*}{ S.D } & $0-20$ & 2.74 & 1.22 & 4.23 \\
\hline & $20-40$ & 2.75 & 1.21 & 3.81 \\
\hline
\end{tabular}

$\mathrm{L}, \mathrm{M}$, and $\mathrm{H}$ stand for low, medium and high respectively. 


\section{Conclusions}

Soil of Swabi was highly calcareous, alkaline in reaction and was found non saline. O.M content in both soil depths was ranged from low to medium, being low in $75 \%$ samples and was found medium in 25\% samples. The application of FYM and green manure was highly recommended to overcome the deficiency of organic matter in Swabi. AB-DTPA Extractable P and $\mathrm{Zn}$ was found high at surface soil than sub surface soil, while AB-DTPA Extractable K was found sufficient at both soil depths. Fe was found adequate in $78 \%$ soil samples at both soil depths and no deficiency of $\mathrm{Cu}$ was observed in all soil samples. Proper fertilization and soil management practices were recommended for such soil to obtain profitable yield.

\section{Conflict of Interest}

The authors declare that there is no conflict of interest.

\section{References}

[1] Q. Shang et al., Soil fertility and its significance to crop productivity and sustainability in typical agroecosystem: a summary of long-term fertilizer experiments in China, Plant and Soil. 381(1-2) (2014) 13-23.

[2] R.A. Khattak, Z. Hussain, Evaluation of soil fertility status and nutrition of orchards, Soil \& Environment. 26(1) (2007) 22-32.

[3] S. Perveen, Z. Malik, W. Nazif, Fertility status of vegetable growing areas of Peshawar, Pakistan, Pak. J. Bot. 42(3) (2010) 1871-1880.

[4] N. Ahmed, M. Rashid, Fertilizer use in Pakistan, NFDC. Planning and Development division, Islamabad, 2003.

[5] M. Imran, Z.A. Gurmani, Role of macro and micro nutrients in the plant growth and development, Science Technology and Development. 1 (2011) 129-131.

[6] M. Razaq, P. Zhang, H.L. Shen, Influence of nitrogen and phosphorous on the growth and root morphology of Acer mono, PloS one. 12(2) (2017) e0171321.

[7] M. Wang et al., The critical role of potassium in plant stress response, International journal of molecular sciences. 14(4) (2013) 7370-7390.

[8] M. Rashid, A.U. Bhatti, Mapping of spatial variability of macro and micronutrients for site specific management, Soil and Environ. 24(1) 2005 34-52.

[9] Wasiullah, A.U. Bhatt, Fertility status evaluation of soil of Kohat and Bannu districts, Sarhad J. Agric. 22(3) (2006) 459-463.

[10] L.A. Richard, Diagnosis and improvement of Saline and Alkali soils, USDA Handbook, 1954.

[11] U.S. Salinity Laboratory Staff, Carbonate and bicarbonate by titration with acid, in: L.A. Richards (Ed.), Diagnosis and improvement of saline and alkali soils. USDA Agricultural Handbook 60. U.S. Government Printing Office, Washington, D.C.USA, 1954.

[12] D.W. Nelson, L. Sommers, Total carbon, organic carbon, and organic matter1, Methods of soil analysis. Part 2. Chemical and microbiological properties, (methodsofsoilan2), 1982, pp. 539-579.

[13] P.N. Soltanpour, Use of AB-DTPA soil test to evaluate elemental variability and toxicity, Commun. Soil Sci. Plant Anal. 16 (1985) 323-338.

[14] R. Irum, U.R. Hafeez, R. Sumbul, Comparative analysis of soil physio-chemical properties of two different districts Peshawar and Swabi, KP, Pakistan, Int. J. Environ. Sci. Nat. Res. 7(2) (2017) 555710. 
[15] R. Latif, S. Ali, R. Hayat, Nitrogen fixation and yield of peanut affected by inorganic fertilizers, variety and inoculums interaction in rainfed areas of Punjab, Soil and Environment. 27(1) (2008) 77-83.

[16] S. Mahmood, M.A. Qazi, I. Ali, Annual Report 2008-09. Soil \& Water Advisory Service in Punjab, Soil Fertility Research Institute, Department of Agriculture, Lahore, 2010.

[17] M. Rashid et al., Role of gypsum in wheat production in rainfed areas, Soil and Environment. 27(2) (2008) 166-177.

[18] G. Sarwar, Use of compost for crop production in Pakistan, Univ. Kassel, Fachgebiet Landschaftsökologie und Naturschutz, 2005.

[19] M. Naseer, D. Muhammad, Direct and residual effect of hazara rock phosphate (HRP) on wheat and succeeding maize in alkaline calcareous soils, Pak. J. Bot. 46(5) (2014) 1755-1761.

[20] N.P. Anderson et al., Applying lime to raise soil $\mathrm{pH}$ for crop production (Western Oregon), Oregon State University, 2013.

[21] M. Zekri, T.A. Obreza, Micronutrient deficiencies in citrus: iron, zinc, and manganese, University of Florida Cooperative Extension Service, Institute of Food and Agricultural Sciences, EDIS, 2003.

[22] S.A. Shahid et al., Baseline soil information and management of a salt-tolerant forage project site in Pakistan, Eur. J. Sci. Res. 27 (2009) 16-28.

[23] E.H. Chaudhry et al., Wheat response to micronutrients in rain-fed areas of Punjab, Soil and Environ. 26(1) (2007) 97-101.

[24] S. Kulshrestha et al., Studies on causes and possible remedies of water and soil pollution in Sanganer town of Pink City, Indian Journal of Environmental Sciences. 7(1) (2003) 47-52.

[25] G. Singh et al., Assessment of soil fertility status under diferent cropping sequences in District Kapurthala, J. Krishi Vigyan. 5(1) (2016) 1-9.

[26] N.C. Brady, R.R. Weil, The Nature and properties of soil, Thirteenth Edition, Macmillan Publishing Co., New York, 2005.

[27] I. Shainberg, J.D. Oster, Quality of irrigation water, International Irrigation Information Center, 1985.

[28] S.J. Qureshi, G. Abbas, S. Bano, Soil fertility status of Quid-i-Azam University of Islamabad Pakistan, J. Bio. Sci. 1(3) (2001) 129-131.

[29] M.T. Saleem, E. Akhtar, CAN fertilizer in Pakistan - a boon or a bane, Farming Out Look. 10(4) (2011) 4.

[30] K.F. Kwong, B. Pasricha, The effects of potassium on growth, development, yield and quality of sugarcane, in: Potassium for sustainable crop production, Proceedings International Symposium on the Role of Potassium in Nutrient Management for Sustainable Crop Production in India, 2002, pp. 430-444.

[31] T.H. Awan et al., Yield response of rice to dynamic use of potassium in traditional rice growing area of Punjab, Pak. J. Agri. Sci. 44(1) (2007) 35-37.

[32] M. Aslam et al., Effect of potash levels and time of applications on seed cotton yield in ecological zone of Rahim Yar Khan, Asian J. Agri. Biol. 2(3) (2014) 172-177.

[33] P.R. Chaudhary, D.V. Ahire, V.D. Ahire, Correlation between physico-chemical properties and available nutrients in sandy loam soils of Haridwar, Journal Chemical Biological and Physiological Science. 2(3) (2012) 1493-1500. 
[34] M. Ahmad, M.J. Khan, D. Muhammad, Response of maize to different phosphorus levels under calcareous soil conditions, Sarhad J. Agric. 29(1) (2013) 43-48.

[35] M. Chohan et al., Relationship of physico-chemical properties and macronutrients indexing at soils of Ghora Bari area district Thatta, Sindh, Pakistan, Soil Environ. 34(1) (2015) 09-14.

[36] M.Y. Arain et al., Soil and plant nutrient status and spatial variability for sugarcane in lower sindh (Pakistan), Pak. J. Bot. 49(2) (2017) 531-540.

[37] F. Ahmad et al., Water soluble iron (Fe) concentration in alkaline and calcareous soils influenced by various Fe sources, Pak. J. Agri. Sci. 51(2) (2014) 407-411.

[38] M. Abid et al., Effect of zinc, iron and manganese on growth and yield of rice (Oryza sativa L.), Pakistan Journal of Agricultural Sciences. 39(3) (2002) 177-180.

[39] E.J. Joy et al., Valuing increased zinc (Zn) fertiliser-use in Pakistan, Plant and Soil. 411(1-2) (2017) 139-150.

[40] A.B. Rafique et al., Effect of zinc and boron in combination with NPK on sunflower (Helianthus annuus L.) growth and yield, J. Biol. Agric. Healthcare. 5 (2015) 101-107.

[41] M. Abid et al., Boron application mitigates salinity effects in canola (Brassica napus) under calcareous soil conditions, Int. J. Agric. Biol. 16 (2014) 1165-1170.

[42] E.J.M. Joy et al., Valuing increased zinc ( $\mathrm{Zn})$ fertiliser-use in Pakistan, Plant and Soil. 411(12) (2017) 139-150.

[43] U.M. Haq et al., Micro nutrients accumulation in effluent irrigated soils of the Korangi industrial area, Karachi, Sindh, Int. J. Agric. Biol. 07 (2005) 214-217.

[44] G.J. Dahar, P.A. Baloch, B.A. Abro, Distribution of micronutrients in different soil series around Tandojam, Sindh, Pakistan, Sci. Tech. \& Devel. 33(1) (2014) 7-13.

[45] Soil Science by A. Rashid; Kazi Suleman Memon; Elena L Bashir; Robyn Bantel. National Book Foundation. Islamabad, 1996. 